\title{
PRESENCE OF WOMEN IN CONFLICT RESOLUTION EFFORTS IN AMBON, SOUTHWEST MALUKU REGENCY OF INDONESIA
}

\author{
Tiwery Weldemina Y.*, Patty Febby $\mathbf{N}$. \\ State Christian Institute of Ambon, Indonesia \\ *E-mail: yudit.tiwery@iaknambon.ac.id
}

\begin{abstract}
The existence of women's important role in the process of resolving the conflict in Ambon. They have been successfully organizing an interfaith meeting to reach an agreement of understanding and conflict resolution. The study was conducted in Ambon of Maluku province. This study uses a qualitative method with a case study approach. Data collected through observation, interviews, and documentation. The results of that research addressing the role of women actively engaged as a squad leader, and also preparing the logistics for the war. The emerging role as a spiritual and religious reaction. woman plays the role of "liaison" community, especially areas where Muslims and Christians live together and they provide a safe place for families. However, efforts to the demonstration of women demanding the termination of the conflict are not addressed. This happens because public awareness of gender is still hindered by the patterns of the traditional understanding of the position and role of women in society.
\end{abstract}

\section{KEY WORDS}

Conflict resolution, women, Ambon, public relations.

The problem of conflict in Indonesia is a social phenomenon that drew public attention. Forms of conflict have led to widespread social violence at various levels of society. As the conflict based on primordial example. Noted conflict the conflict has claimed thousands of lives and forcing no less than 13 million people have become refugees (Colombijn, 2002). Problems associated with identity (ethnicity, nationality, race, and religion) are often the cause of conflicts. The violent conflict in Maluku are mostly concentrated in Ambon is one of the most devastating conflicts that broke out after the fall of the Suharto regime. The conflict claimed nearly 5,000 lives from 1999 to 2002 and displaced a third of the population of Maluku and MalukuNorth (Brow, 2005). Reported after the riots, nearly 200 gangsters Ambon sent back to the Moluccas by the Indonesian Navy (Van Klinken, 1999).

Maluku conflict is often understood as the old hostility between Christians and Muslims have a complexity that is based on historical experience began the colonization period until the formation of the new order of social order. Strategic interests and economic factors are also often contributing to conflict. The conflict in Maluku since January 19, 1999 expired since June 2005 has brought the community in a peace process. According to Trijono (2000), the social conflict in Ambon is caused by the structure inherited from the past. The structure of inter-group relations was formed long ago in the past are still burned into the dynamics of the group now. In Ambon, religious communities play a role in how individuals and groups view themselves. Religion is very instrumental in the construction of identity and the basis for the group to behave.

Conflict efforts involving all elements from the government, religious leaders to women. This resolution conflict process proved the role of women, who are the perpetrators and also the recipient of the impact of the worst conflicts. The Maluku conflict has also led to community Maluku Muslim women, Catholics and Protestants formed Women's Forum Formally with the name of Concerned Women Movement (GPP), a joint forum of the first women in Maluku. In addition, women play an active role in efforts to create peace in Ambon. Interfaith meeting among refugee women not only ensures the distribution of emergency aid to the refugees, but also a place for reconciliation between Muslim and Christian women. Women's leadership in organizing interfaith meeting is an important achievement in the 
Moluccas in conflict resolution efforts. Conflict studies and involvement of women in conflict resolution efforts is important. Therefore, the purpose of this study analyzes motif Conflict and role women in an effort to make the resolution of the conflict.

\section{METHODS OF RESEARCH}

This paradigm puts observation and objectivity in finding a reality or science (Denzin \& Linclon, 2000). Therefore, method this research using a descriptive qualitative method which has been successfully carried out in the city of Ambon. The location selection is done intentionally (purposive) for consideration as a city of Ambon city pluralistic and conflict, Data collected included primary data and secondary data. Primary data were obtained from the observation, in-depth interviews (in-depth interviews) and focus group discussions or focused group discussion (FGD). Secondary data were obtained from the Village Office, the Central Bureau Statistik, Office of population and previous research reports. Data analysis techniques of data collection, data analysis, data reduction, data presentation, and conclusion.

\section{RESULTS AND DISCUSSION}

Louis Kriesberg (1998) mention the origin of identity conflicts a long violent struggle by a communal group such as religious or ethnic recognition for security needs equal access to political institutions and economic participation. Cases of conflict background in Ambon can not be separated from rivalry in the race for public office then escalate into a religious conflict. The highlight of the Maluku conflict itself occurred in the 1999-2002 period that starts from the events of Bloody Maluku on January 19, 1999, which claimed many victims. The conflict itself has been resolved through the Malino I and II in 2002- 2003 represented public figures. The results of the analysis, there are three motives for conflict in Ambon. The first historical motif, where there are two religions that contest in the race for public office. Second, the dominance of one religion that threatens the existence of other religions with the inclusion of intelligent. Third, the riots. conflict is also fueled their religious segregation that occurred between the Muslims and Christians in Maluku that against the background of the weakening of the local leadership. The increasing number of migrants also influence the composition of the population based on religion. The issue of balance between the number of residents formed a communal security perception. The population of Muslims and Christians undergoing change, where the Muslim population increased compared to the population is Christian. in addition, migrants from ethnic Buton, Bugis.

Analysis of the position of women in the social conflict in Ambon approach cultural communication. Cultural communication approach trying to see and explore aspects of female culture in the face of conflict. In the tradition of the social sciences, conflict is a part of the social dynamics of the community(Suseno $F$ 1999). Of course, there is always a characteristic unique uniqueness certain characteristics that are comparable between the conflict (Coleman, 2005). Understand culture will help mapping root causes of conflict and the involvement of women in the conflict arena. Ambon conflict involving women in certain positions and arena. At a certain position of women actively involved as a squad leader, and also prepare logistics for the men who fought. The emerging role as a spiritual and religious reaction, because the conflict in Ambon has been interpreted as a part of a "religious conflict". Emotionality residents appeared in a "defense of religion", and not humanity. During the conflict, women often play the role of "links" that connect the community. in areas where Muslims and Christians live together they provide a safe place for families during times of conflict. Ambon conflict put women and children as victims. The position of women as victims in social conflicts because they become a passive character, and only do the actions evacuation. The position of women has been subordinated by the patriarchal culture in times of conflict. Then women's access to information and the reconciliation agenda is limited or restricted, only for reasons of circumstances not conducive. The position of women as agents of reconciliation Maluku conflict seen two forms of activity, intentional (intended) And 
unintentional (unintended) In the Maluku conflict resolution. The role of women intentional for reconciliation of the two communities can be seen from the existence of Concerned Women Movement.

Table 1 - Chronology of the conflict in Maluku

\begin{tabular}{|c|c|c|}
\hline Year & Month & Chronological \\
\hline \multirow[t]{7}{*}{1999} & January & A small street fights rise to riots in Ambon city and surrounding areas. \\
\hline & March & Mass violence spread to other islands in the Moluccas. \\
\hline & May & The election campaign started and violence is reduced. \\
\hline & June & General election \\
\hline & July. & Mass violence starts again in Ambon city. \\
\hline & October & North Maluku province separated from the province of Maluku. \\
\hline & December & $\begin{array}{l}\text { Silo conflict increased after the church burned and a massacre occurred in the } \\
\text { Muslim village Tobelo }\end{array}$ \\
\hline \multirow[t]{3}{*}{2000} & May & May Laskar Jihad arrived in Ambon. \\
\hline & June & $\begin{array}{l}\text { June massacre in Galela near Tobelo in North Maluku. Police weapons were } \\
\text { stolen and distributed to civil society. }\end{array}$ \\
\hline & December & $\begin{array}{l}\text { Maluku Sovereignty Front (FKM) declared the independence of the South Maluku } \\
\text { Republic (RMS). }\end{array}$ \\
\hline \multirow[t]{2}{*}{2001} & January & $\begin{array}{l}\text { Combined Battalion (Yongab) perform a "cleansing operation" with a target of } \\
\text { Muslim militants. }\end{array}$ \\
\hline & June & Yong performs "cleansing operations" other. \\
\hline \multirow[t]{4}{*}{2002} & February & Peace Agreement (Malino II) was signed. \\
\hline & April & $\begin{array}{l}\text { Maluku provincial government offices were burned. Soya village was attacked } \\
\text { after the violence began to decrease in the Moluccas }\end{array}$ \\
\hline & May & The leader of Laskar Jihad, Ja'far Umar Talib and FKM, Alex Manuputti arrested. \\
\hline & October & Laskar Jihad is missing from the Moluccas. \\
\hline \multirow[t]{2}{*}{2003} & May & Civil emergency lifted from the province of North Maluku. \\
\hline & September & Civil emergency lifted from the province of Maluku. \\
\hline \multirow[t]{2}{*}{2004} & April & FKM RMS flag, sparking riots in Ambon that killed 40 people. \\
\hline & June & General election \\
\hline
\end{tabular}

Source: Literature Review.

Maluku conflict is a multidimensional conflict. This conflict was triggered by a fight a young man with public transportation drivers in Batu Merah. Then grew into a conflict that dragged two different religious communities into it. The growing political importance along with the escalation of the conflict that continues to escalate make politicized religion as part of the Maluku conflict. The number of deaths of women and children is significant in Ambon conflict, conflict indicates gender bias. But the concept of gender bias, not solely because of the number of female victims. But gender bias interpreted as a deviation to the right of public access to women. The shape of the deviation due to the strengthening of the role of men in various social activities that took place during the conflict. Gender bias condition is a condition women do not have access to determining the attitude in resolving the conflict. Demonstration Efforts women demanded a cessation of conflict are not addressed as part of gender bias. Gender awareness is still hindered by the patterns of the traditional understanding of the position and role of women in society. The pattern is often determined by the construction of cultural understanding. In times of conflict women's voices represent the voices of victims and often ignored. Although some of them engage directly mediate the warring factions and help find a way out of violent conflict. There also are strengthening the role of civil society in addressing existing conflicts and prevent violence in the future. Conflict resolution efforts carried out intentionally by women visible from several meeting initiated by women two religious communities which then spawned the Women's Movement matter. The movement emerged to establish communication between the warring religious communities in Ambon city. This movement then becomes a bridge women's level grassroots to access government officials (male) and advocate for women's issues during the conflict. 


\section{CONCLUSION}

The role of women actively involved as a squad leader, and also prepare logistics for the men who fought. The emerging role as a spiritual and religious reaction. woman plays the role of "liaison" community, especially areas where Muslims and Christians live together and they provide a safe place for families. But the efforts of women demonstration demanding a cessation of conflict are not addressed. Gender awareness is still hindered by the patterns of the traditional understanding of the position and role of women in society in Maluku.

\section{REFERENCES}

1. Brown, Graham, Wilson, Christopher and Hadi, Suprayoga.2005. Overcoming Violent Conflict: Peace and Development Analysis in Maluku and North Maluku. Vol. 4, Bappenas, Jakarta: United Nations Development Program and the Indonesian Institute of Sciences.

2. Coleman and Eric Marcus.2006. The Handbook of Conflict Resolution Theory and Practice. Second EditionSan Francisco, Jossey Bass

3. Colombijn Freek and J Thomas Lindblad 2002. Eds Roots of Violence in Indonesia. Singapore ISEAS

4. Louis Kriesberg, 2003. Constructive Conflicts From Escalation to Resolution. Maryland: Rowman and Littlefield Publishers Inc.

5. Suseno, Franz Magnis,1999. Pemikiran Karl Marx Dari Sosialis Utopis ke Perselisihan Revisionisme, PT. Gramedia Pustaka Utama, Jakarta.

6. Trijono L. 2001 Exit From Crisis Maluku. Yogyakarta: Student Library Yanuarti Sri others 2003. Conflict in Central Maluku Cause Characteristics and Long-Term Settlement LIPI Jakarta

7. Van Klinken, Gerry, 1999. "What the caused the Ambon violence?" Inside. Indonesia. 